\title{
Fact checking audiovisual en la era de la posverdad. ¿Qué significa validar una imagen?
}

\section{Audiovisual fact-checking in the post-truth era: What does it mean to validate an image?}

\author{
Aaron Rodríguez-Serrano. Universitat Jaume I. España. \\ serranoa@uji.es \\ $[\mathrm{CV}]$ (D) \\ María Soler-Campillo. Universitat Jaume I. España. \\ solerm@uji.es \\ $[\mathrm{CV}]$ (D)
}

Javier Marzal-Felici. Universitat Jaume I. España.

marzal@uji.es

$[\underline{\mathrm{CV}}]$ (D) $\mathrm{G}$

Financiación: El presente texto ha sido realizado en el marco del proyecto de investigación Análisis de identidades discursivas en la era de la posverdad. Generación de contenidos audiovisuales para una Educomunicación crítica (AIDEP)", código 18I390.01/1, bajo la dirección de Javier Marzal Felici, financiado por la Universitat Jaume I a través de la convocatoria competitiva de proyectos de investigación, para el periodo 2019-2021.

Cómo citar este artículo / Referencia normalizada

Rodríguez-Serrano, A.; Soler-Campillo, M. y Marzal-Felici, J. (2021). Fact-checking audiovisual en la era de la posverdad. ¿Qué significa validar una imagen? Revista Latina de Comunicación Social, 79, 19-42. https://www.doi.org/10.4185/RLCS-2021-1506

\begin{abstract}
RESUMEN
Introducción: Este artículo pretende explorar el amplio debate teórico sobre las relaciones que se establecen entre las imágenes y la complejidad de aplicar sobre ellas conceptos de verdad. Un vistazo a las agencias de Fact Checking contemporáneas demuestra que los bulos y las fake news usan con más frecuencia materiales audiovisuales para respaldar sus mensajes. Metodología: Se realiza una revisión del corpus teórico sobre las relaciones entre imagen y validación/verdad, ejemplificando los límites de las ideas dominantes con análisis de casos basados en el análisis textual. Resultados: Los límites de las relaciones entre verdad y texto audiovisual fueron enunciados por primera vez al hilo de los debates fenomenológicos sobre el realismo, y posteriormente matizados -entre otras- por las escuelas semiótica, los estudios culturales y la actual eclosión de las teorías "postdigitales". En el marco de dichas teorías se ha generado una tensión a partir de las marcas de veredicción (pixelado, bajos formatos, ruido visual, glitch) y la desafección de la ciudadanía con las imágenes distribuidas por los medios de comunicación oficiales. Conclusiones: En un mundo en el que los medios convencionales cada vez tienen menos capacidad para distribuir imágenes e influir en sus interpretaciones, es necesario replantearse que la validación de las imágenes es una competencia fundamental en la creación de la ciudadanía del futuro. De ahí que la introducción de competencias críticas de lectura audiovisual en los niveles educativos de la
\end{abstract}


enseñanza obligatoria sea la única manera de poner en crisis la propia naturaleza "referencial" de las imágenes.

\title{
PALABRAS CLAVE:
}

Imagen; Posverdad; Representación; Semiótica; Desinformación; Análisis textual; Fact-cheking.

\begin{abstract}
Introduction: This paper aims to explore the broad theoretical debate on the relationships that are established between images and the complexity of applying concepts of truth on them. A look at contemporary Fact Checking agencies shows that hoaxes and fake news more frequently use audiovisual materials to support their messages. Methodology: A review of the theoretical corpus on the relationships between image and validation/truth is made, exemplifying the limits of the dominant ideas with case analyses based on textual analysis. Results: The limits of the relationship between truth and audiovisual text were first enunciated in the phenomenological debates on realism, and subsequently nuanced -among others- by the semiotic schools, cultural studies and the current emergence of "post-digital" theories. Within the framework of such theories, a tension has been generated from the marks of verediction (pixelation, low formats, visual noise, glitch) and the disaffection of the citizenry with the images distributed by the official media. Conclusions: In a world where conventional media have less and less capacity to distribute images and influence their interpretations, it is necessary to rethink that the validation of images is a fundamental competence in the creation of the citizenship of the future. Hence, the introduction of critical audiovisual reading skills at compulsory education levels is the only way to challenge the very "referential" nature of images.
\end{abstract}

\section{KEYWORDS}

Image; Post-truth; Representation; Semiotics; Disinformation; Textual analysis; Fact-cheking.

\section{CONTENIDO}

1. Introducción. 2. Objetivos. 3. Metodología. 4. Discusión. 4.1. De la verdad del texto audiovisual y su (hipotética) verificación. 4.2. A favor de la posibilidad de la posición. Apología del fact checker audiovisual. 5. Reflexiones finales. 5.1. Las imágenes en la era de la posverdad. 5.2. La educación mediática: una emergencia política, social, educativa y cultural. 6. Referencias.

\section{Introducción}

La relación entre verdad e imagen es, sin duda, uno de los grandes problemas teóricos que se pueden acometer desde los campos del estudio audiovisual, y muy concretamente, desde las disciplinas estrictamente vinculadas con el análisis formal y temático de los contenidos audiovisuales. Si bien, como veremos, en los años cincuenta la pregunta comenzó a tomar forma desde una dimensión estrictamente fenomenológica que, posteriormente, tendría que atravesar diferentes reformulaciones semióticas, marxistas y postestructuralistas, actualmente nos encontramos ante un panorama que, sin ser estrictamente nuevo, sí que nos resulta indudablemente más urgente. Con la irrupción de la llamada posverdad (Rodríguez, 2018; Zunzunegui y Zumalde, 2019), la apelación a una cierta irracionalidad de la audiencia y a la creencia en elementos explícitamente afectivos por encima de su disquisición racional ha acelerado dramáticamente los usos propagandísticos y manipuladores de los contenidos audiovisuales. Azuzado por algoritmos que buscan explícitamente la polarización de contenidos en redes sociales (Lanier, 2020) -y por medios de comunicación que, como ha demostrado la reciente crisis del Covid-19 (López-Rico, González-Esteban y Hernández-Martínez, 2020), participan activamente de la misma estrategia-, la necesidad del replanteamiento de los flujos de creación y difusión de contenidos en nuestro campo ha adquirido una nueva urgencia. En este 
sentido, cabe señalar que el contexto de la pandemia por el Coronavirus nos ha permitido constatar con bastante claridad que la desinformación puede considerarse como un rasgo propio del discurso político -institucional, y también desde las fuerzas políticas de la oposición, con importantes diferencias entre ellas- que, además, tiene un impacto directo sobre la actividad de los ciudadanos prosumers en la creación y expansión de bulos sobre la pandemia (Pérez-Curiel y Velasco Molpeceres, 2020: 108-109).

Como demuestra un vistazo rápido a muchas de las agencias de verificación (Newtral, EFE Verifica o Maldita.es), el ejercicio crítico de análisis suele realizarse mediante una metodología de comprobación que remite explícitamente a la tradición de la lógica y los llamados "juicios apofánticos" (Aristóteles, 1982), es decir, a la comprobación de aquellos enunciados que pueden tener exclusivamente un valor de verdad -entendida aquí en su dimensión netamente positivista-. Dicho con más claridad: en el ámbito del periodismo escrito o de las declaraciones de los responsables políticos, la validación puede consistir -y va de suyo, no suele ser fácil-, en la aplicación de una metodología de contraste entre el enunciado que dice algo de lo que ocurre en lo real y la serie de indicadores, más o menos cuantificables, que ofrece la experiencia factual de dicho acontecimiento. Ahora bien, un vistazo apresurado al ejercicio concreto y cotidiano de estas agencias demuestra, sin el menor género de duda, que el cotejo de datos ya no puede dar de lado el análisis, más o menos elaborado, de los materiales audiovisuales.

Pongamos un simple ejemplo que clarifique definitivamente esta idea de partida. Si tomamos como referencia el artículo 37 bulos y mitos sobre las vacunas que nos están intentando colar publicado por Maldita.es en su sección de ciencia el pasado 5 de febrero de 2021, podremos proponer algunas intuiciones de partida interesantes. En primer lugar, se trata de un hilo en constante actualización que pretende clarificar los efectos de la vacuna frente a las teorías de la conspiración y los autodenominados "grupos revisionistas" que, siempre apoyándose en técnicas propias de la posverdad -muerte de niños recién vacunados, extrañas organizaciones ocultas que pretenden el control de la población-, reinventan o manipulan las informaciones científicas. Lo primero que nos llama la atención es que más de la mitad de los bulos han tenido forma de imágenes: memes compartidos, supuestas fotos de responsables políticos realizando declaraciones, fotomontajes descontextualizados de otras catástrofes humanitarias atribuidas a la vacuna, etc. Es interesante, además, que el espectro visual de los contenidos maliciosos sea tan amplio que cubra desde lo que podríamos llamar, recordando a Barthes (1989), un "grado cero de la escritura científica" encarnado en esas supuestas "gráficas" que comparan explícitamente la correlación entre la vacuna de la gripe y el riesgo de infección por coronavirus, hasta la pura invención fantástica de esquelas de supuestas víctimas del proceso de vacunación. 


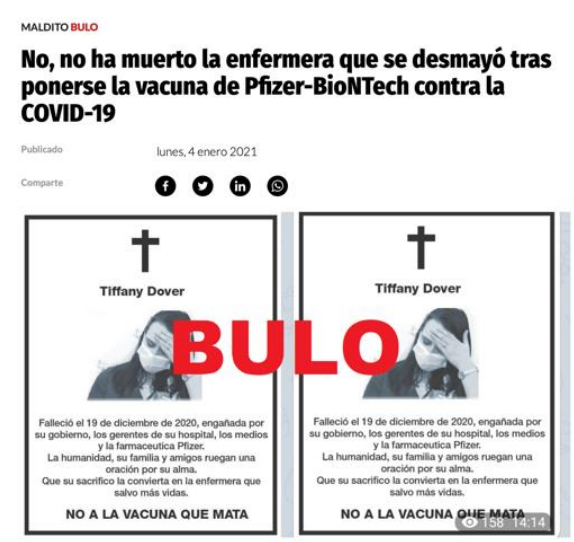

Imagen 1. Falsa esquela de una enfermera fallecida por haberse inyectado la vacuna de Pfizer.

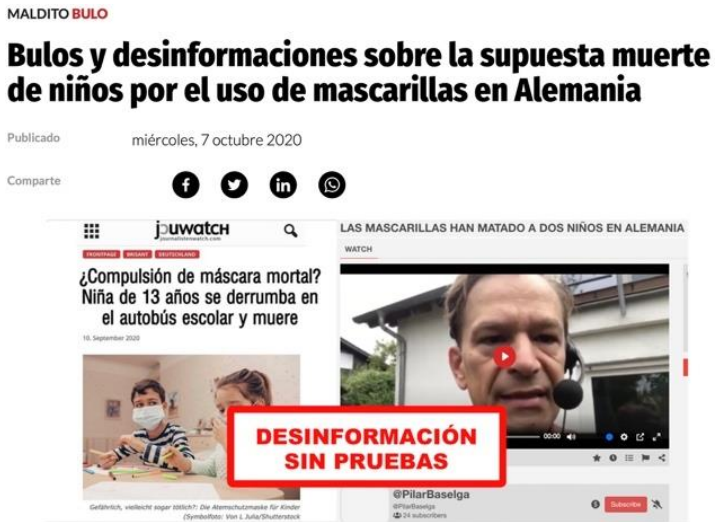

Imagen 2. Bulos sobre el riesgo por el uso continuado de mascarillas en niños.

Fuente. Maldita.es

Fuente. Maldita.es

Del mismo modo, un rasgo que nos parece también relevante es que en no pocas ocasiones se hace referencia a imágenes distribuidas por medios de comunicación tanto locales -la radiotelevisión pública de Marbella- como internacionales -la cadena 7 News de Australia--, para canibalizar el prestigio y los propios procesos de cotejo y comprobación de medios "profesionales". Así, la manipulación pasa por apropiarse, a modo de "argumento de autoridad", de aquellos canales de comunicación que, en otras ocasiones, son tachados de "desinformativos" o "negacionistas".

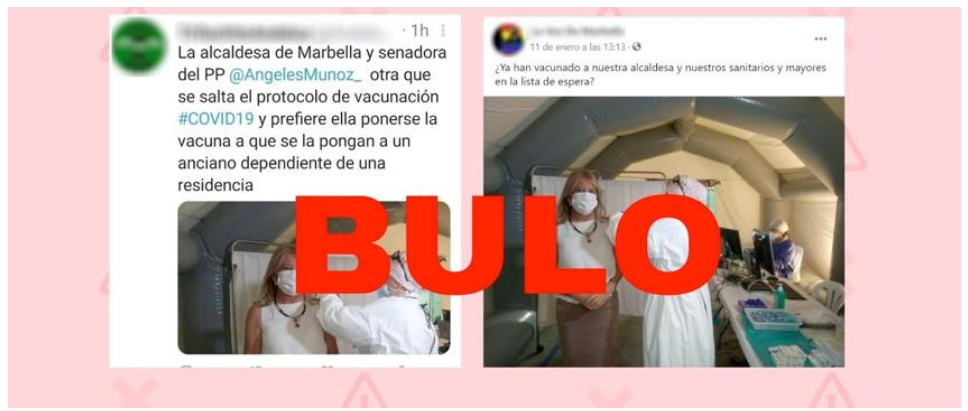

Imagen 3. Bulo de la radio local de Marbella. Fuente. Twitter

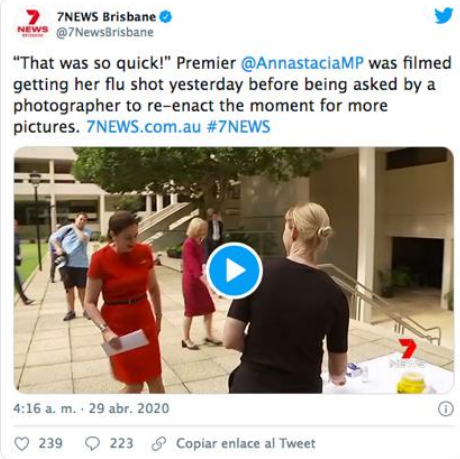

Imagen 4. Captura del tuit de la cadena de TV australiana.

Fuente. Twitter

El debate actual sobre el fact checking sitúa en primer plano la reivindicación de un periodismo de calidad, donde la "verificación de datos" constituye una de las principales competencias de los profesionales del periodismo, en un contexto en el que los medios tradicionales, sumidos en una transformación muy profunda, en el nuevo escenario digital -en el que las redes sociales son hegemónicas y las empresas informativas están tratando de optimizar sus recursos al máximo- han pérdido valor, relevancia e, incluso, cierta legitimidad en nuestra sociedad (Ufarte-Ruiz, PeraltaGarcía y Murcia-Verdú, 2018). En este sentido, debe destacarse el enorme esfuerzo realizado por las empresas informativas y agencias especializadas en fact checking, una actividad ya consolidada en el periodismo europeo y norteamericano, especialmente para hacer frente al fenómeno de las fake news y de la desinformación (Vázquez-Herrero, Vizoso y López-García, 2019). Sin duda, los procesos de 
verificación encierran una notable complejidad y el trabajo de equipos multidisciplinares que dirigen su atención, de manera muy especial, a la circulación de declaraciones políticas e informaciones que circulan por las redes sociales (Ufarte-Ruiz, Anzera y Murcia-Verdú, 2020).

Por otra parte, como han puesto de manifiesto diferentes estudios, el fenómeno de las fake news cuya complejidad fenomenológica no se puede ignorar, abarcando amplias tipologías como la "infopublicidad", la "propaganda", las "noticias satíricas", la "fabricación de noticias", etc. (RomeroRodríguez, Valle Razo y Torres Toukoumidis, 2018)- debe enmarcarse en un contexto de expansión de la lógica del entretenimiento que ha engendrado una constelación de formatos híbridos (Han, 2018) -“infotainment", "advertainment", "politainment", “edutainment", etc.-, que ya anunciara hace décadas Guy Debord en el marco de la nueva sociedad del espectáculo (1999). De este modo, no debe extrañarnos que la expansión de las noticias falsas se produzca entre colectivos sociales de niveles educativos y culturales bajos, entre quienes tienden al pensamiento mágico y esotérico, y desconfían del conocimiento científico (Castillo-Riquelme, Hermosilla-Urrea, Poblete-Tiznado, y Durán-Anabalón, 2021).

En definitiva, la propagación de las imágenes antes aludidas muestra a las claras nuestro punto de partida: el fact checking no puede realizarse sin una serie de competencias en lectura crítica de las imágenes que vaya más allá de la simple constatación veredictiva de enunciados escritos concepción tradicionalista y positivista de la verdad-, sino que debe tomar en cuenta aquellos elementos temáticos y formales que son específicos tanto de la fotografía como del discurso audiovisual. Veamos, por tanto, cómo podemos contribuir desde nuestra disciplina al debate sobre sus procesos y sus sistemáticas de trabajo.

\section{Objetivos}

En una gran parte de la bibliografía del campo, además de los contenidos lingüísticos (Mottola 2020), se hace hincapié en la relevancia que las infografías o los elementos estrictamente visuales juegan a la hora de combatir las diferentes desinformaciones (Pedriza, 2017), lo que necesariamente nos lleva a la cuestión de que la reflexión sobre las capacidades "significantes" de la imagen (Zunzunegui, 1995), deben estudiarse tanto desde la recepción como desde la creación. En efecto, siguiendo las ideas básicas trazadas por Català Domènech (2019), es incomprensible que las nuevas generaciones de creadores y creadoras audiovisuales separen teoría y praxis en compartimentos estancos, siendo precisamente nuestra época un momento histórico crítico para recuperar el pensamiento en, y sobre, la creación de contenidos audiovisuales. Nuestro objetivo principal en las siguientes páginas, por lo tanto, será realizar una síntesis de aquellos temblores teóricos más relevantes en los choques establecidos entre la imagen y la verdad, actualizando en lo posible los pasos ya trazados en el contexto de la actividad crítica contemporánea.

Obviamente, no se trata de hacer aquí una revisión bibliográfica de la cuestión -campo en el que, por lo demás, ya contamos con más que notables precedentes (Quintana, 2003; Zumalde y Zunzunegui, 2015) -, sino de proponer una aproximación necesariamente impresionista a aquellos núcleos que consideramos más relevantes en la situación contemporánea de las teorías de la imagen para explorar su relación directa con la problemática que supone una buena praxis del fact-checking. Obviamente, nuestra aproximación opta por el enfoque ensayístico, ya que consideramos que en un texto que pone claramente la cuestión de la verdad en primer término admite -como ha ocurrido en la bibliografía específica del campo- la posibilidad de proceder no tanto mediante juicios conceptuales herméticos, sino antes bien, mediante la intuición, la reflexión crítica y la referencia abierta a otros pensadores y pensadoras. 
De cara a sistematizar nuestro propósito, proponemos los siguientes objetivos específicos:

O1: Topografiar brevemente la discusión clásica entre las relaciones entre imagen y verdad en el contexto de la verificación de noticias.

O2: Valernos de las diferentes etiquetas contemporáneas para la clasificación y reflexión crítica de las imágenes (de las teorías estrictamente iconoclastas a la cada vez más frecuente apología de las "imágenes pobres") para, posteriormente, intentar comprender dónde se encuadran las imágenes desinformativas, pero ante todo, cuáles son sus huellas de veredicción ( $\mathrm{y}$ en qué compleja situación nos encontramos. Se utiliza el término "veredicción", utilizado por Greimas (1990), que sería equivalente a la expresión "fehaciente" o "acción y efecto de establecer con certeza algo", y que se podría asimilar al concepto de "veracidad".

O3: Por último, reflexionar sobre los retos que debe afrontar el sistema educativo en la formación de fact checkers y de educadores con competencias avanzadas de análisis de la imagen.

\section{Metodología}

A tenor de lo anterior, se puede comprobar que nuestra aproximación parte de una metodología crítica de análisis del discurso en la que se propone una primera fase de reflexión crítica y síntesis sobre la base teórica sobre la que se asienta el proceso de fact checking audiovisual, una segunda fase de actualización bibliográfica y conceptual, y por último, una tercera fase proactiva claramente vinculada con la actualización de perfiles académicos y profesionales en el campo de la educomunicación. Es necesario aclarar, por lo tanto, que nuestro objetivo principal es la clarificación teórica y epistemológica del problema, y no tanto la creación de una nueva metodología de trabajo. En efecto, a lo largo del artículo haremos referencia a diferentes pautas, estructuras y maneras de aproximarse a las relaciones entre verdad e imagen, y en ellas podrá encontrar el lector interesado el planteamiento de todo tipo de metodologías hermenéuticas y veredictivas.

Como ya ha quedado sugerido en el epígrafe introductorio, nuestro enfoque de trabajo es heredero directamente de los estudios semióticos estructurales y críticos sobre los medios de masas (González Requena, 1988; Zunzunegui, 2005), especialmente en lo tocante a la naturaleza audio-visual de la imagen. Si bien es cierto que las bases de dicho campo quedaron principalmente sedimentadas en el terreno de los estudios fílmicos (Aumont y Marie, 1990; Casetti, 1996), una reciente nómina de trabajos sigue demostrando su efectividad en campos netamente contemporáneos como el análisis de los populismos (Palao Errando, 2016), la ficción serial (Iturralde, 2021) o los videojuegos (MartínNúñez y Navarro Remesal, 2021). A nuestro juicio, y como intentaremos demostrar, las técnicas de verificación de las imágenes pueden mostrar tanto las oportunidades como los límites de nuestro propio enfoque.

En lo que toca a la lectura de los ejemplos escogidos para desplegar esos contenidos teóricos, nos valdremos tanto de los conceptos clásicos de la narratología audiovisual (Gómez Tarín, 2011), como de aquellos otros parámetros específicamente vinculados a las diferentes metodologías de análisis textual (Marzal-Felici y Gómez Tarín 2007) que permitan atender al texto como espacio de significación $\mathrm{y}$, por lo tanto -y de esto nos ocupará gran parte del trayecto que sigue-, como verificación.

\section{Discusión}

\subsection{De la verdad del texto audiovisual y su (hipotética) verificación}


Hace ya unos años, tuvimos ocasión de plantear una aproximación a la cuestión que hoy nos ocupa (Rodríguez Serrano, 2017) en la que pusimos de manifiesto la dificultad de tomar los materiales audiovisuales como simple enunciados apofánticos sobre los que delimitar su capacidad de decir la verdad. En aquel momento tomamos un enfoque netamente fenomenológico y no exento de problemas - especialmente, en lo tocante a las posibilidades desveladoras de la imagen- que, a tenor de lo ocurrido en la esfera pública en los últimos años, requiere urgentemente un replanteamiento extenso.

En un contexto político marcado por los mecanismos de control basados en el miedo (Nussbaum, 2019) o en la inestabilidad de los discursos (Levitsky y Ziblatt, 2018; Mounk, 2018), la reivindicación de un estatuto de verdad en las imágenes tiene poco menos que un sabor netamente quijotesco. En relación directa con la crisis académica de las humanidades -y del destronamiento de un saber cualitativo por un aparentemente más riguroso procedimiento cuantitativo (Zunzunegui y Zumalde, 2018)-, no es de extrañar que los mecanismos audiovisuales de la posverdad emerjan como consecuencia directa de los excesos cometidos en las últimas décadas por la espectacularización de los media (Palao Errando, 2009), los mecanismos de la llamada telerrealidad, y finalmente, el confuso marasmo comunicativo de las redes sociales.

Frente a este confuso panorama, nos parece sensato comenzar señalando las dos polaridades opuestas, las dos opciones teóricas que puntúan ambos lados del extremo: la de la mínima y la máxima fe en la posibilidad de las imágenes. La primera de ellas, como es bien sabido, hunde sus raíces en las teorías de la iconoclasia tradicional, y por lo tanto, niega cualquier tipo de conexión de verdad entre la imagen y su referente histórico, político o social. Debemos señalar, además, que dichas posturas son absolutamente relevantes en el debate sobre los medios de comunicación contemporáneos sobre el tratamiento mediático de la pandemia mundial. No es de extrañar que las teorías de los iconoclastas florecieran, muy precisamente, a la sombra del trauma. Inspirados en los planteamientos documentales de Claude Lanzmann (2011) y en ocasiones mal digeridos por ciertas posiciones dogmáticas auspiciadas por una acelerada apropiación de ciertos planteamientos lacanianos (Wajcman, 2001), los nuevos iconoclastas niegan cualquier verificación de la imagen histórica traumática. Lo que las cámaras recogen siempre es un resto, una simbolización incompleta, una información no deseada a la que inevitablemente se le acaban colgando las etiquetas de "obsceno", "no ético", o muy especialmente, a partir del célebre escrito de Jacques Rivette (2010) "abyecto". El contacto entre la audiencia y lo real traumático únicamente puede tener lugar mediante técnicas vinculadas con la narración, el recuerdo, o los mecanismos de la llamada "post-memoria" (Hirsch, 2001), pero no con la posibilidad de la imagen de decir algo sobre lo ocurrido.

Esta postura se puede ejemplificar con mayor claridad en la portada de The New York Times del domingo 24 de Mayo de 2020: 


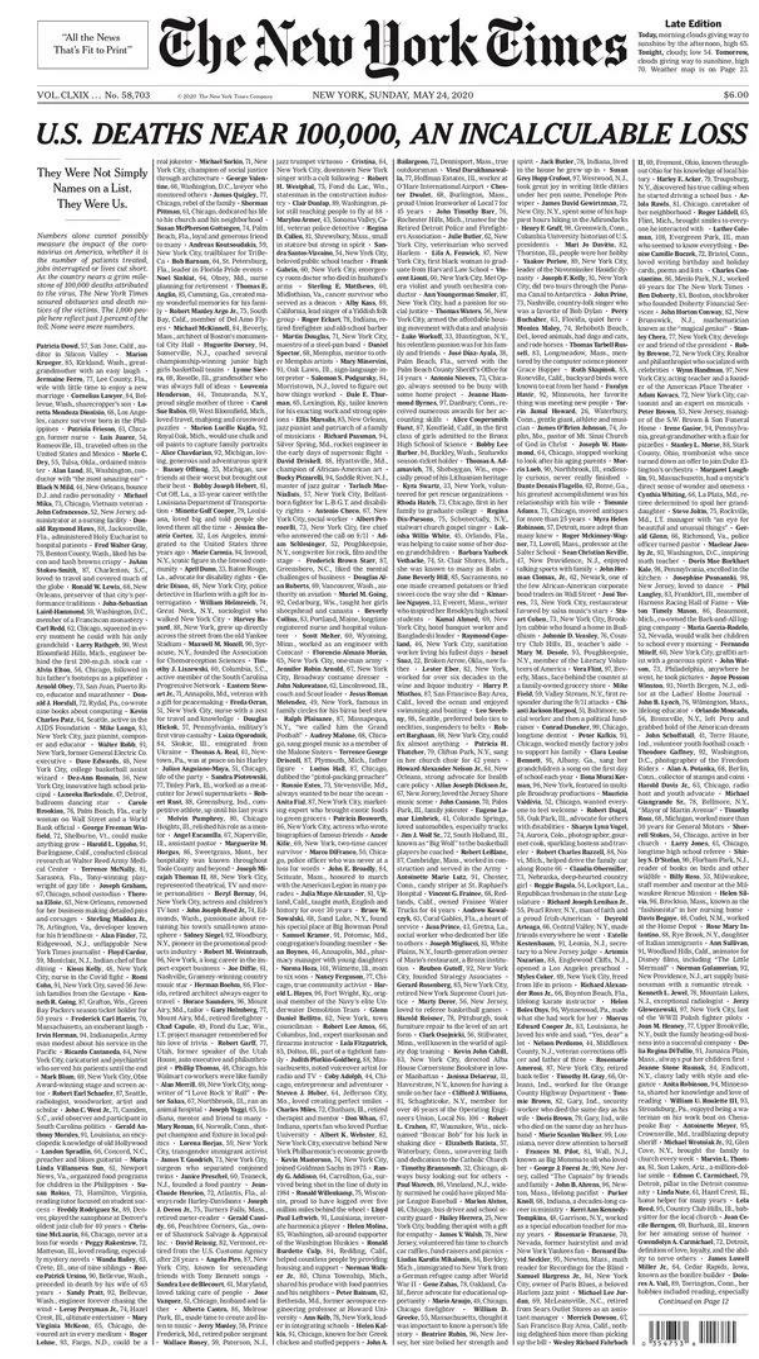

Imagen 5. Portada del 24 de Mayo de 2020

Fuente. The New York Times

Ampliamente celebrada como un ejercicio de sutileza periodística, la portada del New York Times rechaza explícitamente el uso de imágenes y organiza, en su lugar, el duelo como una cuestión estrictamente logocéntrica y difusamente narrativa. Las seis columnas que componen la mancheta muestran, precisamente, que a su juicio el recuerdo parece refractario a la imagen misma, a aquello que Bazin denominó la capacidad de "momificación del tiempo" (2001), negando así su función memorialista y prefiriendo directamente la escritura del nombre y una brevísima reseña de los méritos de vida (su profesión, su función familiar, su ideología política). La construcción visual de la portada habla por su sobriedad, por su referencia a los célebres mausoleos que han jalonado la historia de las catástrofes del siglo XX -del Monumento a la Puerta de Menin al Memorial de Bykivnia, por poner únicamente dos ejemplos-, depositando la labor de recuerdo en el fuera de campo visual. Es obvio que esos nombres fueron rostros, pero la magnitud de la catástrofe pandémica hace imposible la reproducción de todas sus imágenes y -esto es lo que más nos interesa, las teorías iconoclastas señalarían que la reproducción de los archivos de su vida no ofrecería ningún "plus informativo" o incluso "afectivo" -más bien al contrario- que no quede ya precisamente hilvanado con la reproducción de sus nombres y sus biografías. 
Como bien sospechará el lector, en la lógica iconoclasta no tiene sentido hablar de verificación, ya que la misma idea es sospechosa y carente de sentido. Sin embargo, esta idea puede ser fácilmente puesta en crisis por la obra de otra serie de teóricos para los que, muy al contrario, resulta imposible entender el ecosistema de informaciones y afecciones que domina el mundo sin tomarse muy en serio la capacidad significante de las imágenes, y por lo tanto, la necesidad de generar procesos de discusión y verificación alrededor de las mismas. Como bien señala Didi-Huberman: "Sabemos que el iconoclasta sólo odia tanto las imágenes porque, en el fondo, les atribuye un poder mucho mayor que el que le concede el iconófilo más convencido" (2004: 101). Para desplegar esta idea, tomemos ahora como ejemplo la polémica fotografía de Fernando Lázaro de El mundo que sirvió de portada el 8 de abril de 2020, tomada en el interior de la pista del Palacio de Hielo que sirvió como morgue improvisada para las víctimas del Covid-19.
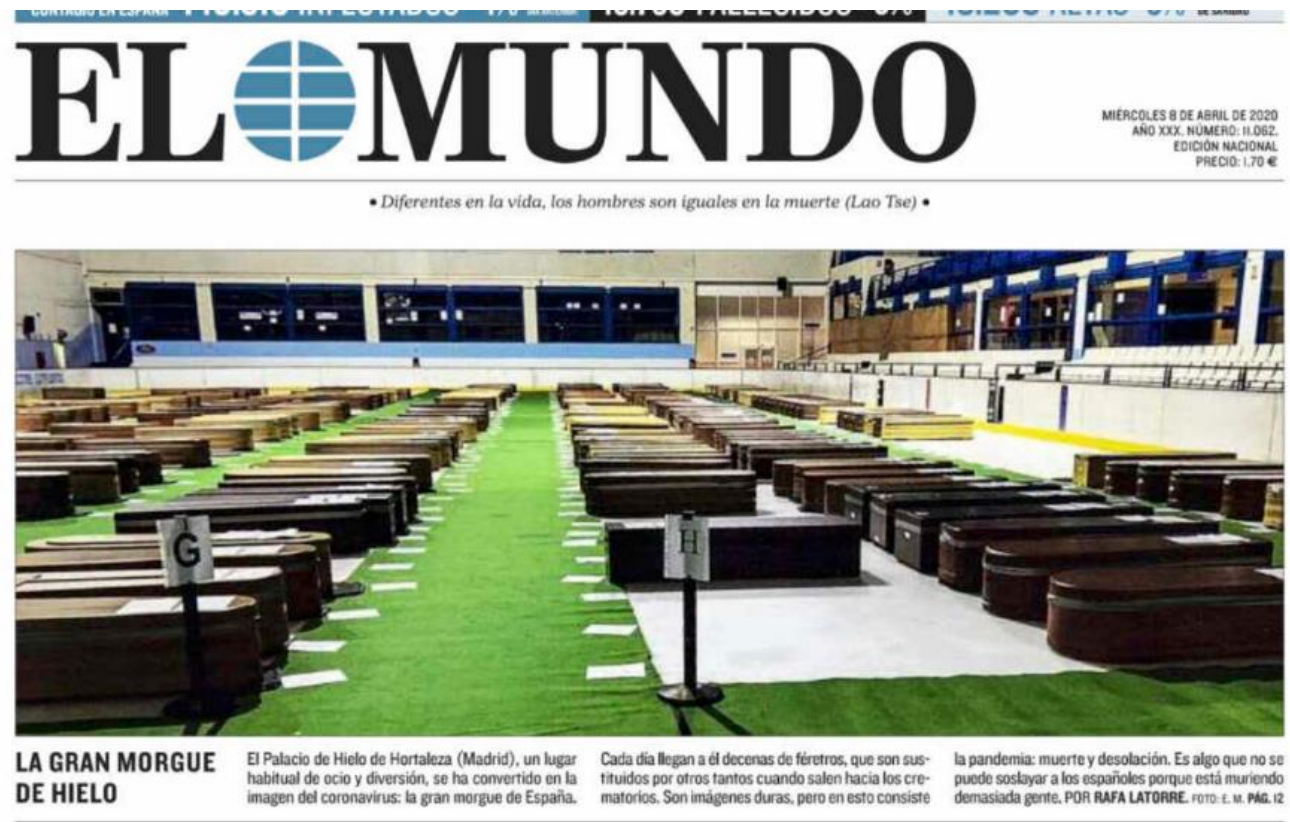

Imagen 6. Portada del 8 de Abril de 2020

Autor. Fernando Lázaro

Fuente. El Mundo

Ciertamente, los postulados de los iconoclastas volvieron a ponerse de manifiesto tras el inevitable alud de preguntas que siguió en los medios y en las redes sociales a la presentación de la fotografía. El proceso de duelo, generalmente situado en el fuera de campo visual de los medios, había emergido con toda su crudeza. En un nivel de verificación muy básico, la imagen ya contaba con suficientes huellas de veredicción: había sido publicada por un diario de reconocido prestigio y seriedad nacional, venía firmada por un profesional de trayectoria intachable, y aparentemente, no se podía detectar en su reproducción un uso fraudulento, ilegítimo, o vinculado a ningún programa ideológico que quisiera aprovechar su contenido mediante una lectura parcial para generar algún tipo de rédito político o económico. En un segundo nivel, de hecho, la imagen ofrecía jugosas contradicciones visuales que hubieran podido servir para poner en crisis algunos de los inevitables cortocircuitos sociológicos que despertó la pandemia: el contraste descarnado entre comercio -recordemos que el Palacio de Hielo era una macrocentro comercial situado en el barrio de Hortaleza, diseñado según lo cánones habituales del intercambio económico postindustrial (Friedberg, 1993)- y duelo, la incapacidad de las sociedades postmodernas para reactivar los mecanismos de simbolización de la comunidad o la muerte (Lyon, 2000), e incluso la manera en la que lo real acaba fagocitando la aparente pureza de las heterotopías propias de los llamados no-lugares (Augé, 2005) que configuran 
nuestro tiempo. La cuestión de la ruina -que ya había empezado a anunciarse en la construcción visual de la crisis económica de 2008 (Apel, 2015; Marzal-Felici y Soler-Campillo, 2018)- alcanza aquí una nueva dimensión donde la problemática de la validación no puede pasar únicamente por la comparación entre un real y un imaginario, sino que exige una auténtica "toma de posición" -en el sentido, de nuevo, esbozado por Didi-Huberman (2013) - en la que el medio de comunicación decide erigirse como portador de memoria a partir de una selección que, en este caso, tiene sus debilidades y sus fortalezas exclusivamente en el punto de vista fotográfico.

La fotografía de Fernando Lázaro, más allá de los juicios personales que pueda suscitar en cada lector, nos sirve para contraponerla con el tristemente célebre fotomontaje que, apenas unos días antes, el partido político Vox había compartido en sus redes sociales, y en el que, de alguna manera, sobrevolaba la sombra de lo real que poco después emergería en la portada reproducida en El mundo.

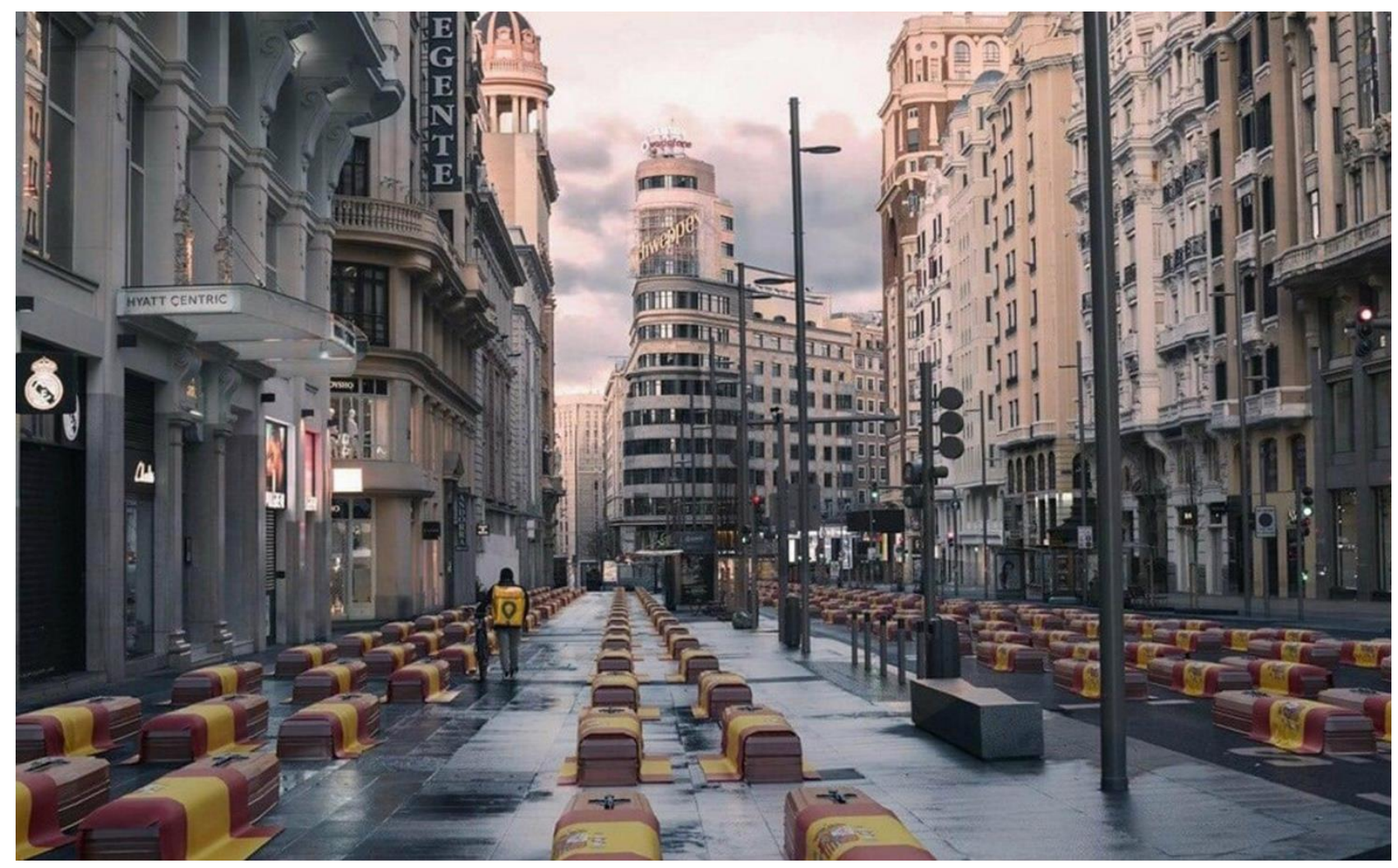

Imagen 7. Fotomontaje ofrecido por Vox en sus redes sociales sobre una fotografía original de Ignacio Pereira

Fuente. Cuenta de Twitter de Vox

Ciertamente, el caso de Vox resulta interesante por la manera en la que reactualiza también los debates entre imagen ficcional e imagen histórica que habían emergido al hilo de la retransmisión en directo de los atentados del 11S (González Requena, 2002; Žižek, 2002). Con ciertas salvedades, eso sí, que atañen directamente al proceso de la verificación. En primer lugar, una de las marcas de veredicción aparentemente más sólidas del proceso - el origen o la fuente de la información- generó un extraño precedente. Si un partido situado en la esfera democrática y con una base de votantes nada despreciable se sentía legitimado para manipular lo real fotográfico sin ofrecer una pista de lectura sobre la manipulación de los significantes - esto es, sin avisar de que se trataba de un fotomontaje o una reapropiación "simbólica"-, es sin duda porque sus parámetros de verdad no coinciden, en principio, con los que cabría esperar de un cierto fair play político. En primer lugar, 
porque por la propia configuración de la imagen se aprecia un uso tendencioso y claramente malintencionado de la identidad de la víctima. De igual modo que en la portada del New York Times se reflejaba de manera inevitable la lógica del pensamiento individualista norteamericano -cada víctima es una frase, un logro aislado casi siempre vinculado a su actividad profesional, un pequeño american dream encapsulado que no termina sino de sugerir la complejidad del conjunto total de los fallecidos-, la imagen no-verificable de Vox actúa en una dirección opuesta: todas las víctimas, todos los ataúdes -invitamos a la comparación con la fotografía real de El mundo- están coronados por dos potentes operadores simbólicos: un crucifijo y una bandera de España. Es decir, todas las víctimas tienen una identidad patriótica y religiosa, haciendo de su muerte una suerte de pieza claramente vinculable con el proyecto nacional y católico que el propio partido propone. Llevada al extremo, la lectura de la imagen únicamente puede sugerir dos cosas: que las únicas víctimas reivindicables son las suyas -los muertos no católicos o no patrióticos deben ser expulsados, de nuevo, al fuera de campo-, o bien que todas las muertes son, en esencia, muertes ideológicas veladas ante la supuesta ineptitud de los responsables de las medidas frente a la pandemia.

En paralelo a la más que espinosa lectura textual de la imagen, y de nuevo en términos estrictos de verificación, lo que llama nuestra atención es que la fotografía manipulada pertenece a nuestro tiempo con escalofriante precisión por la ya citada quiebra en la fiabilidad de la fuente -un partido político que se dice democrático, esto es, preocupado por la responsabilidad de su relación con la verdad para el pueblo-, pero no menos importante, su precisa transmisión mediante una red social (Twitter), cuyo compromiso con las mínimas normas de formación de la ciudadanía son, cuanto menos, discutibles (Keller et al., 2020; Pierri, Piccardi and Ceri, 2020). Como ya señaló Todorov en su diagnóstico sobre los enemigos de la democracia:

Los impulsores de movimientos populistas suelen mirar con buenos ojos internet y las redes sociales, ya que esta difusión de la información escapa a todo control centralizado y al consenso democrático. Es una revancha de la periferia sobre el centro, del extremismo sobre la moderación. El discurso privado que circula en la red no debe someterse a las obligaciones que pesan sobre los discursos públicos (Todorov, 2012: 152).

Por lo tanto, reenfocando la cuestión que mantiene abierto el debate entre iconoclastas y teóricos a favor de un uso verificable de las imágenes, podemos señalar al menos una posible vía por las que la teoría puede circular actualmente sin caer en las trampas del populismo o del "todo vale" propio de los adalides de la posverdad.

\subsection{A favor de la posibilidad de la posición. Apología del fact checker audiovisual}

Jacques Rancière, en uno de sus más célebres trabajos sobre la naturaleza de lo irrepresentable (2011), señalaba que los problemas del debate sobre la correcta mostración de un acontecimiento debían pasar explícitamente por la reflexión sobre el contexto, y no tanto por el cierre "absoluto" o la incapacidad de transmitir con precisión absoluta la "esencia" de un acontecimiento. El problema del decir no está en el tema -categoría absoluta a la que resulta insensato, además de poco realista, exigir una objetividad o transparencia total-, sino más bien en lo que cada analista hace con los límites del decir de cada imagen. Es ahí donde entra el problema capital del fact checking: la asunción de un cierto fracaso, un déficit que en nada empaña la necesidad de su ejercicio. Dicho con mayor claridad: verificar una imagen es siempre hacer una afirmación parcial con respecto al enfoque y profundidad de su contenido, situar en el marco de una cierta lectura, generar unas coordenadas que permitan no tanto su clasificación apofántica como verdadera o falsa, sino simplemente -y aquí se encuentra, a nuestro juicio, la clave-, analizar con precisión y rigor sus procesos de significación. 
No se equivocará, sin duda, quien detecte tras esta idea una traslación más o menos afortunada de la figura tradicional del analista textual $-\mathrm{y}$, por extensión, de una de nuestras metodologías más estimadas, el análisis crítico del discurso-, en la figura contemporánea del fact checker. Como suele ocurrir en los procesos históricos, precisamente una vez que las modas parecían haber relegado -al menos, en lo tocante a la Academia Universitaria- al análisis de las imágenes a una discreta posición (Nieto Ferrando y Aranzubía Cob, 2020; Rodríguez Serrano, Palao Errando y Marzal-Felici, 2019), se produce un inevitable "retorno de lo reprimido" de manos de la propia urgencia derivada de nuestros déficits educomunicativos. En una sociedad en la que -volveremos sobre esta idea-, se han potenciado planes de estudio basados en mecanismos de clara inspiración neoliberal (educación para las empresas) a costa de recortar en competencias humanísticas o de reflexión crítica, de pronto nos encontramos con la inevitable paradoja de la polarización salvaje, la desinformación rampante y, en nuestro caso concreto, la absoluta imposibilidad de una gran parte de la ciudadanía para leer el torrente de mensajes que recibe. Obviamente, la posición no pasa únicamente por generar "agencias de verificación" que funcionen con transparencia, rigor y la máxima claridad posible, sino en paralelo, llevar esta necesidad social a su extremo: poner sobre la mesa, de una vez, que no se puede ser un ciudadano responsable de sus propias decisiones en el siglo XXI sin tener unas competencias mínimas de crítica del discurso audiovisual.

La cuestión de la "democratización" de las imágenes, como ocurrió con tantos otros logros paradójicos- del siglo XXI, surgió desde luego de las mejores intenciones. Cuando los pioneros de la contracultura norteamericana -estamos pensando, concretamente, en el célebre On Film Journalism and Newsreels de Jonas Mekas (recogido en Kahana, 2016)- comenzaron a celebrar la expansión de las cámaras de bajo formato (8 y 16 milímetros), no pensaron únicamente en reformular todo el sistema audiovisual, desde la crítica hasta la exhibición (Mekas, 2013), sino muy concretamente, en hacer visible mediante una toma de conciencia de las posibilidades de la imagen a aquellos colectivos que habían permanecido tradicionalmente alejados de los códigos narrativos y estilísticos tanto del periodismo dominante como de las ficcionalizaciones propias del Modo de Representación Institucional. El surgimiento del underground en Estados Unidos (Mendik y Jay Schneider, 2002), generó efectos palpables en campos como el feminismo o las identidades LGTB+ que acabarían, con el pasar de los años, cristalizando en las academias por la vía de los Estudios Culturales. Sin embargo, una simple mirada a parte de la bibliografía contemporánea sobre la relación entre la "legitimidad" de las imágenes - de nuevo, el problema de sus "marcas de veredicción" y los procesos para sistematizar su contextualización y juicio por parte de las agencias- y su estatuto de verdad no únicamente parece haberse desplazado más bien poco de las posiciones iniciales de Mekas, sino que, en los casos más extremos, podemos incluso detectar una suerte de efecto-aberrado de las mismas. Merece la pena detenerse en esta idea.

Quizá la teórica más relevante en lo que toca a las relaciones entre verdad y formato audiovisual sea la alemana Hito Steyerl. A partir de su más que estimulante reflexión sobre las "imágenes pobres" (Steyerl, 2014), la autora proponía una suerte de celebración de las estrategias estéticas que surgían de la ciudadanía: imágenes rodadas con teléfonos móviles, de baja calidad, montadas con software libre y distribuidas directamente por internet. Técnicas como el glitcheado, el pixelado o la reivindicación del "ruido digital" no eran únicamente "marcas de veredicción", sino profundas posiciones político-estéticas que garantizaban no únicamente la verdad sino también la legitimidad de un decir ciudadano. Steyerl contraponía el sistema a las "imágenes perfectas" que distribuía la CNN o los medios de comunicación dominantes, basadas en un uso del encuadre y el ruido visual tradicional. La lógica de Steyerl, sin duda, formaba parte tanto de su consistente aparataje intelectual como de su propia praxis en el campo del ensayo audiovisual, donde ya había experimentado con el rodaje con teléfonos móviles -Abstract (2012) - o con cromas y técnicas de motion capture puramente rudimentarias -Liquidity Inc (2014) o Factory of the Sun (2015)-. Si traemos a colación 
su pensamiento no es únicamente como un extraordinario quiebro a los planteamientos iconoclastas, sino precisamente por la reactualización inteligentísima desplegada sobre las teorías seminales de Mekas y sus discípulos.

Ahora bien, como apuntábamos, el problema mayor al que se enfrentan actualmente los fact checkers que trabajan en el campo de la imagen es, precisamente, que desde el negacionismo, las posiciones de la teoría de la conspiración o los movimientos que buscan explícitamente crispar a la ciudadanía se ha heredado de manera natural ese dominio de la "imagen pobre". Basta con realizar un barrido rápido por los vídeos vinculados al movimiento anti-vacunas al que hacíamos referencia al comienzo del artículo para realizar una breve sistematización de los recursos audiovisuales que nos surgen al paso: subtitulados con faltas de ortografía, supuestas "pruebas" extraídas de bancos de imágenes -en ocasiones, con la propia marca de agua-, utilización de grandes bloques de texto o de emojis propios de los interfaces de TikTok o Instagram. Las emisiones "extraídas" de "telediarios internacionales" no esconden su pixelado y los cortes de montaje muestran discontinuidad entre el raccord, así como entre las pistas de vídeo y el audio original. Es la mano inexperta del sujeto que decide "reeditar" o "reapropiarse" - valga la referencia irónica a la estrategia artística propia del arte contemporáneo- de los materiales ajenos la que pone de manifiesto su propia incapacidad para controlar las "marcas de veredicción" normativas, desplomándonos así en una paradoja: las imágenes pobres de Steyerl -y, digámoslo claramente, también proyectos educativos y creativos tan profundamente discutibles como el bricoleur del propio Rancière (véase la afilada y muy pertinente crítica vertida en Alonso-García, 2010)-, acaban desembocando en un callejón sin salida: de igual modo que el documental tuvo que rechazar finalmente su incapacidad para encontrar una estrategia indudable de encuentro y transmisión con la realidad, en el flujo contemporáneo de mensajes audiovisuales no hay una estrategia única ni un proceso indudable que permita calcular y sistematizar los grados de verdad. Y, como señalábamos anteriormente, por mucho que las agencias de verificación estén generando un trabajo ímprobo, nuestra apuesta es todavía más radical y descansa en esa petición tantas veces repetida y tan pocas escuchada: la formación de una ciudadanía crítica capaz de realizar una labor autónoma -por pequeña que sea- en la lectura de las imágenes.

\section{Reflexiones finales}

\subsection{Las imágenes en el horizonte de la posverdad}

Es evidente que las imágenes tienen un papel protagonista en la sociedad de la desinformación, por su omnipresencia y capacidad para despertar, en ocasiones credulidad, en otras para provocar entre los espectadores las reacciones más diversas -sobre todo emocionales-, apropiándonos de ellas cuando las ponemos en circulación en las redes sociales. De este modo, nunca antes "la imagen había experimentado tantos desgarramientos, tantas reivindicaciones contradictorias y tantos repudios cruzados, tantas manipulaciones inmorales y execraciones moralizantes" (Didi-Huberman, 2012:10). En primer lugar, las imágenes tienen una incidencia muy directa en la construcción del imaginario colectivo, por lo que poseen un marcado carácter antropológico, en tanto que contribuyen a construir la identidad colectiva y sus desarrollos en la vida pública (Belting, 2007), cuyo campo de batalla principal son las redes sociales (O1). En segundo lugar, la forma de las imágenes, en tanto que representaciones discursivas, presenta características textuales que nos hablan del punto de vista que encierran y de la articulación del punto de vista de una instancia enunciativa, que enmascara -con mayor o menor disimulo- una ideología o visión de mundo, que puede permanecer más o menos invisible, pero nunca está completamente ausente, porque la representación nunca puede ser absolutamente transparente, a pesar que de que el régimen actual de las imágenes es el de la hipervisibilidad. En este sentido, el análisis de las imágenes desinformativas que circulan por las 
redes sociales o que se enmarcan en contextos informativos, nunca son "inocentes", siempre muestran huellas de veredicción desde la perspectiva del análisis textual (O2).

Como han señalado diversos autores, desde un punto de visto estrictamente discursivo, hablar de "posverdad", de discursos de "engaño y tergiversación", parecería manifestar la existencia de "reductos discursivos prístinos, despolitizados y de orden cuasi religioso" (Carrera, 2018: 1471). Desde el pensamiento semiótico, el discurso informativo o documental siempre es un artificio retórico, porque la enunciación que todo discurso profiere nunca es trasparente. Por ello, el cine documental -basado en la construcción del "efecto de sentido" de la "ilusión de lo real"- no puede ser más "real" que el cine de ficción, puesto que obedecen a estrategias de construcción de sentido distintas (Carrera y Talens, 2018; Zumalde y Zunzunegui, 2019).

Pero las imágenes son también producciones simbólicas, que guardan una estrecha relación con sus contextos culturales y, por tanto, encierran una fuerte carga ideológica que se relaciona con el entorno político, económico, social y cultural, donde surgen. Algunos estudiosos atribuyen el auge de las fake news y de la desinformación a cierto ambiente académico generado en las universidades occidentales en las últimas décadas, donde parecería haberse alimentado cierta aversión a la verdad y a los hechos (Andrade, 2013), una interpretación que parece ignorar la naturaleza del pensamiento posmoderno, cuya raíz es marcadamente deconstruccionista y crítica contra los grandes relatos de la tradición occidental, entre los que destaca "el orden de lo real" -la "posverdad"-, que Lyotard puso en crisis en su conocida obra La condición posmoderna (1987).

Hemos hecho referencia a imágenes que circulan por las redes sociales, que necesitan de una "validación", que permita determinar su "valor de verdad", con la ayuda de los fact checkers y de las necesarias agencias de fact checking. Pero, ¿qué ocurre con otros tipos de imágenes, como las fotografías que publican los grandes medios, que están acreditadas por agencias de noticias de reconocido prestigio o por premios de fotoperiodismo internacionales? ¿Acaso no presentan elementos expresivos, narrativos y enunciativos que revelan -por definición- la existencia de un "sesgo" ideológico? Un breve examen de algunas imágenes puede ayudarnos a clarificar esta cuestión.

La fotografía de F. Dilek Uyar (Imagen 8), ganadora de la categoría "Street Photography" del prestigioso Sony World Awards de 2021, una de tantas imágenes que hemos podido ver sobre la pandemia del Coronavirus, presenta un alto nivel de complejidad formal. Se trata de una composición con profundidad de campo, con colores muy saturados que expresan la idea de conflicto -mediante el fuerte contraste de tonalidades entre la dominante naranja del interior de los vagones de metro y la dominante azulada del andén- que se suma al contraste de nitidez entre el interior del vagón y la neblina del exterior del andén. En la imagen destaca, coincidiendo con el centro de fuga, la figura del empleado que está desinfectando este espacio con un producto químico, una actividad muy habitual en esta época de pandemia. Se trata de tonalidades con fuerte saturación de color que consiguen construir una imagen con una fuerte pregnancia, que posee un marcado carácter espectacularizador, construyendo una vista que provoca el extrañamiento del espectador.

La imagen 9 es una fotografía de Emilio Morenatti, de la agencia Associated Press, que muestra la imagen de un sanitario - conocido como "recolector de cadáveres"- que arrastra una camilla en la que se puede ver un cuerpo completamente cubierto por una bolsa mortuoria, con una composición en profundidad de campo, acentuada por las paredes de un estrecho pasillo, que provoca una sensación de asfixia y desazón en el espectador. 


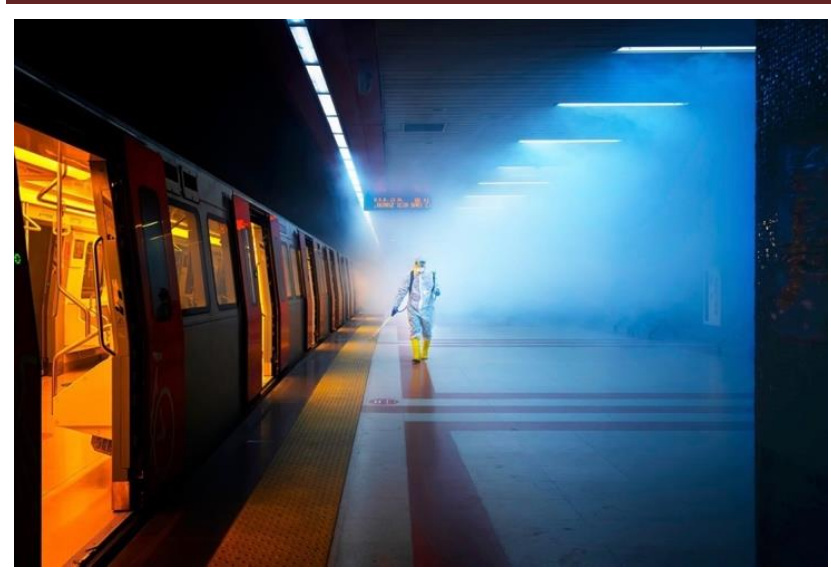

Imagen 8. Fotografía de F. Dilek Uyar, ganadora de la categoría "Street Photography". Estación de tren de Ankara.

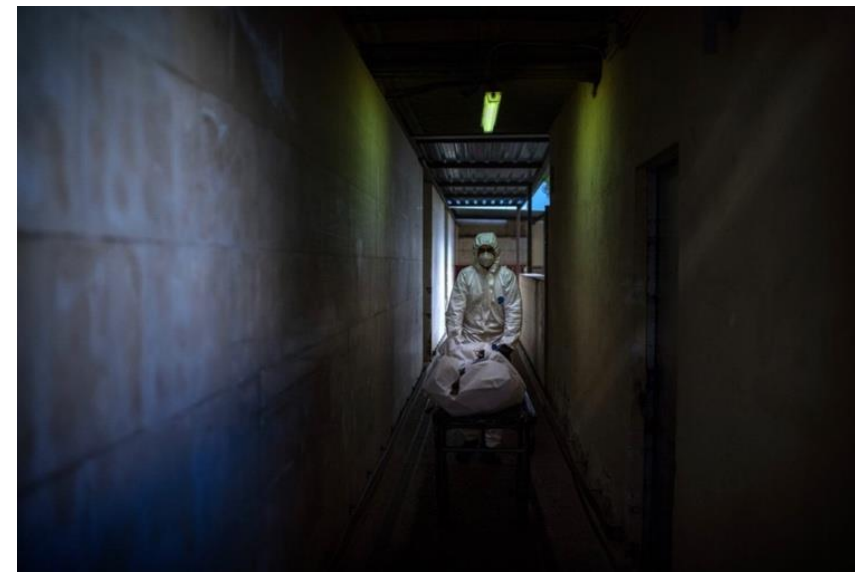

Imagen 9. Fotografía de Emilio Morenatti Fuente. Associated Press

Fuente. Sony World Photography Awards 2021

Finalmente, el retrato de una doctora, al término de su jornada laboral en un hospital de la ciudad de México, tomada el 19 de mayo de 2020 por el fotógrafo Iván Maicas, permite tomar conciencia de la dureza extrema de la labor que desarrolla esta profesional -y todo el personal sanitario, por extensión- que, tras una larga jornada laboral, permite ver en su rostro la huella de las gafas de protección y de la mascarilla. Como si se tratara de un retrato tradicional, la doctora mira a cámara, trasunto del espectador, haciendo gala de transparencia enunciativa: la extrema nitidez de la imagen se convierte en un elemento visual que reclama la solidaridad del espectador. Se trata de una fotografía que nos interpela, y que nos invita a identificarnos con la protagonista y a solidarizarnos con su situación. 


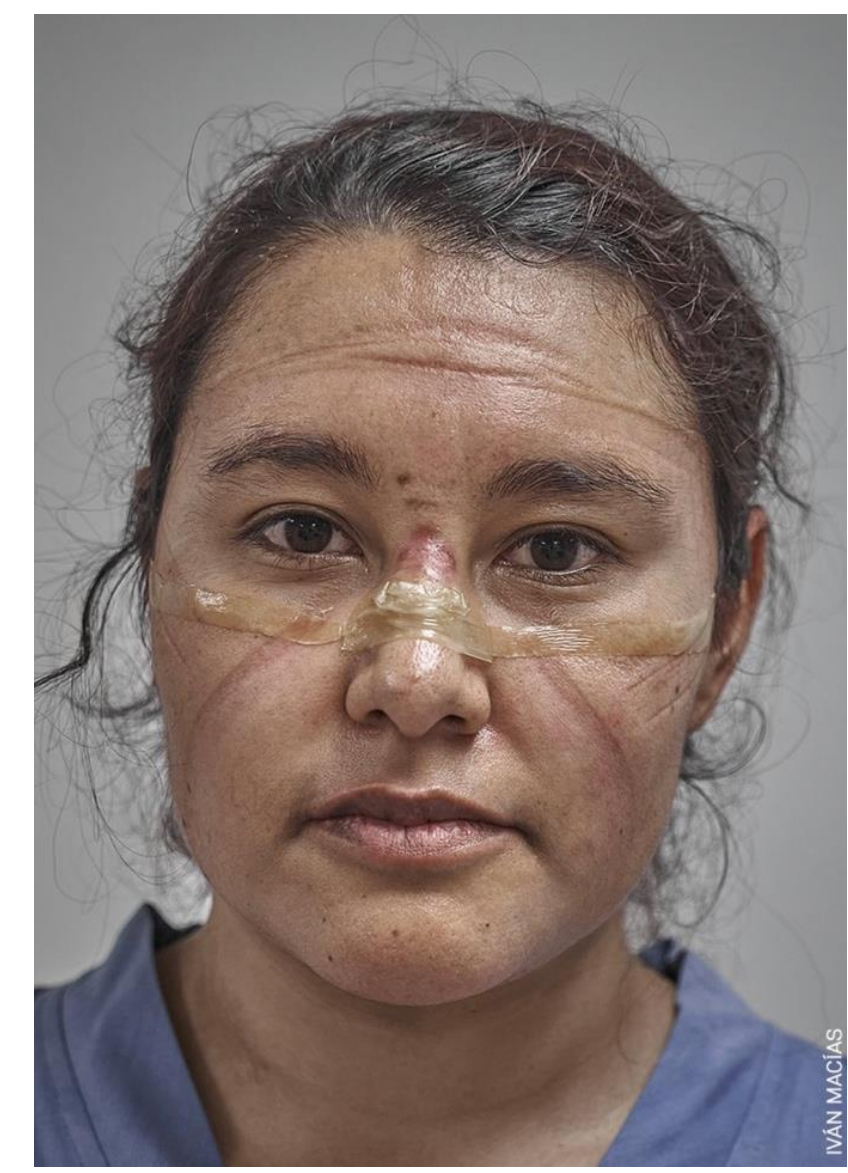

Imagen 10. Fotografía de Iván Macías. Fotografía finalista en la categoría "Portrait"

Fuente. World Press Photo 2021

Estos pocos ejemplos pueden servirnos para ilustrar que el trabajo de validación de imágenes debe verse complementado con la realización de análisis textuales, que permiten comprender cómo construyen significación, un ejercicio necesario para tomar conciencia del carácter discursivo y construido de cualquier texto visual (Marzal-Felici, 2007; Marzal-Felici, 2021).

El actual contexto de desinformación, y de fuerte presión al que se ven sometidos los profesionales del periodismo, ha de llevar a reclamar otras formas de ejercerlo. Es obvio que la sobreinformación y la infoxicación, y un hambre insaciable por rentabilizar el trabajo de los periodistas desde la dirección de muchas empresas informativas -cuyos empleados se encuentran en situación de precariedad laboral hasta límites insospechados- sólo puede neutralizarse con la asumción de otras formas de entender el periodismo como el llamado "slow journalism", cuyas prácticas es necesario reivindicar (Barranquero Carreto y Jaurrieta, 2016; Romero-Rodríguez, Tejedor y Castillo-Abdul, 2021).

En los últimos años, diversos informes intitucionales han puesto de manifiesto la necesidad de articular políticas para combatir la desinformación, principalmente a través de la llamada "information literacy", a través de iniciativas impulsadas desde el Consejo de Europa (Wardle y Derakhshan, 2017; Chapman y Oerman, 2020). Porque no debemos ignorar que, incluso entre muchos ciudadanos, supuestamente formados en el uso de las nuevas tecnologías, existe también cierto "analfabetismo funcional": no se trata de manejar las tecnologías de información y de la comunicación, sino de saber utilizarlas críticamente. Algunos investigadores constatan la presencia 
de "analfabautas", esto, personas que carecen "de la capacidad crítica y de la competencia mediática suficiente para el correcto filtrado de los contenidos que consume, crea y comparte" (RomeroRodríguez y Rodríguez-Hidalgo, 2019: 388). En este contexto, la educación mediática constituye una necesidad social de primer orden.

\subsection{La educación mediática: una emergencia política, social y cultural}

El tercero de los objetivos (O3) que planteaba este manuscrito se refería a la necesidad de examinar los retos que debe afrontar nuestro sistema educativo en la formación de fact checkers y de educadores con competencias avanzadas de análisis de la imagen y educación mediática.

Existe una coincidencia clamorosa entre los estudiosos de la educomunicación a la hora de señalar que la manera más eficaz de combatir las fake news y el contexto de la desinformación es a través de la construcción de "una ecología de medios o 'infodieta' que equilibre tanto la relación cuanticualitativa de la información que recibimos, como también nos permita desinfoxicarnos paulatinamente de la sobrecarga de contenidos vacíos..." (Aguaded y Romero-Rodríguez, 2015: 54). En efecto, el nuevo escenario digital ha generado un espacio mediático en el que los usuarios, en tanto que prosumers, también comparten y producen contenidos que, con frecuencia, viralizan y replican las fake news, agravando así la desinformación que sufrimos. La metodología del fact checking debe verse, por tanto, como una aportación importante para mejorar la calidad del periodismo, pero también para mejorar las competencias mediáticas de los ciudadanos (LoteroEcheverri, Romero-Rodríguez y Pérez Rodríguez, 2018). Algunas agencias especializadas en fact checking como Maldita.es, Newtral o Verficat.cat, tienen, entre otras, una amplia oferta formativa, dirigida a un público amplio, desde centros de educación secundaria, universidades e, incluso, asociaciones y colectivos ciudadanos.

Así pues, la alfabetización o educación mediática es una herramienta necesaria para aprender a diferenciar entre imágenes manipuladas y no retocadas (Domínguez-Rigo, 2020) pero, sobre todo, para aprender a leer críticamente las imágenes (y también para crearlas), entendiendo que toda imagen es una construcción discursiva, que nos ofrece una determinada visión del mundo, en tanto que resultado de un acto enunciativo.

Actualmente es motivo de preocupación la baja calidad de nuestro sistema mediático, la multiplicación de la telebasura y que las redes sociales se han convertido en un altavoz de bulos y fake news, incluso de conductas como el ciberbullying o acoso escolar e, incluso, para acelerar la circulación de mensajes de odio. En efecto, se constata que en los últimos años algunos pocos medios de comunicación han tomado la iniciativa a la hora de aplicar el fact checking, lo que, sin duda, puede interpretarse como un proceso de autorregulación profesional, absolutamente necesario para mejorar la calidad del periodismo (Gallardo-Camacho y Marta-Lazo, 2020). Pero no se puede olvidar que la aplicación de estas técnicas repercute positivamente en la reputación de las empresas informativas, un intangible de enorme valor en medio de la fuerte crisis reputacional que sufre el periodismo, especialmente, en nuestro país. En este sentido, cabría señalar que todavía carecemos en España de un Consejo Audiovisual, que preveía nuestra Constitución de 1978, un órgano independiente que serviría, entre otras cosas, para realizar una labor de vigilancia y, al tiempo, de promoción de buenas prácticas en el periodismo y en la comunicación.

Medio siglo después de la llegada de la democracia a nuestro país, en plena crisis por la pandemia del Coronavirus de 2020, a la grave crisis sanitaria se ha sumado la multiplicación de fake news, la expansión de un entorno de desinformación e infoxicación y la crisis de un sistema educativo que no estaba preparado para la formación no presencial y para los retos de la nueva sociedad digital. Hace 
unos meses, el profesor Joan Ferrés constataba que todavía hoy los planes de estudio de los Grados de Maestro/a en Educación Infantil y en Educación Primaria de las universidades españolas presentan un grave déficit de formación en el campo de la educación mediática, que incluye no sólo competencias en el uso de las tecnologías educativas, sino también el desarrollo de capacidades críticas, sensibilidad y creatividad para analizar y crear mensajes audiovisuales (Ferrés, 2020). Dada la extraordinaria relevancia que tiene la comunicación en nuestra sociedad, parece un anacronismo realmente grave que la formación mediática y audiovisual no tenga una presencia mayor en todo el sistema educativo y, como sería lógico, también en los planes de estudios de los Grados en Educación, así como en el Máster de Formación del Profesorado.

Esta situación ha motivado la redacción de un manifiesto titulado "La Educomunicación en España: Un reto urgente para la sociedad digital", a iniciativa de los profesores Ignacio Aguaded, de la Universidad de Huelva, y Javier Marzal Felici, de la Universitat Jaume I, que cuenta con el apoyo de 100 profesores de referencia en los campos de la comunicación y de la educación de nuestro país, para reclamar a la administración pública acciones para impulsar avances en este terreno. El documento, que se puede consultar en https://www.edu-comunicacion.es, propone la creación de Dobles Grados en Maestro/a en Educación y en Comunicación, con el fin de formar a educadores con altas competencias en comunicación, lo que sería de gran ayuda para introducir cambios profundos en nuestro sistema educativo. Una propuesta de trabajo que sería de indudable relevancia para comprender mejor la enorme complejidad que encierra la pregunta "¿Qué significa validar una imagen?".

\section{Referencias}

Aguaded, Ignacio; Romero-Rodríguez, Luis M. (2015). Mediamorfosis y desinformación en la infoesfera: Alfabetización mediática, digital e informacional ante los cambios de hábitos de consumo informativo. Education in the Knowledge Society, vol. 16, núm. 1, 2015, pp. 44-57. https://doi.org/10.14201/eks20151614457

Alonso-García, L. (2010). Peliculeros zarandeados en la selva de las cosas y los signos. Revista Shangrila, 22, 14-33.

Andrade, G. (2013). El posmodernismo. ¿Vaya timo! Laetoli.

Apel, D. (2015). Beautiful Terrible Ruins: Detroit and the Anxiety of Decline. Rutgers University Press.

Aristóteles (1982). Lógica. Gredos.

Augé, M. (2005). Los no lugares. Espacios del anonimato: Una antropología de la sobremodernidad. Gedisa.

Aumont, J. y Michel, M. (1990). Análisis del Film. Paidós.

Barranquero Carretero, A. \& Jaurrieta Bariain, G. (2016). Slow Journalism in Spain: New Magazine Startups and the Paradigmatic Case of Jot Down. Journalism Practice, 10(4): 521-538. https://doi.org/10.1080/17512786.2015.1124729

Barthes, R. (1989). El grado cero de la escritura. Siglo XXI. 
Bazin, André (2001). ¿Qué es el cine? Rialp.

Carrera, Pilar (2018). Estratagemas de la posverdad. Revista Latina de Comunicación Social, 73, 1469 a 1481. http://www.revistalatinacs.org/073paper/1317/76es.html

Carrera, Pilar; Talens, Jenaro (2018). El relato documental. Efectos de sentido y modos de recepción. Cátedra.

Casetti, F. (1996). El film y su espectador. Cátedra.

Castillo-Riquelme, V.; Hermosilla-Urrea, P.; Poblete-Tiznado, J. P.; Durán-Anabalón, C. (2021). Noticias falsas y creencias infundadas en la era de la posverdad. Universitas. Revista de Ciencias Sociales y Humanas de la Universidad Politécnica Salesiana, 34, pp. 87-108. https://doi.org/10.17163/uni.n34.2021.04

Català Domènech, J. M. (2019). La puesta en imágenes. Conceptos de dirección cinematográfica. Shangrila.

Chapman, Martine; Oermann, Markus (2020). Supporting Quality Journalism through Media and Information Literacy. Strasbourg: Council of Europe. https://edoc.coe.int/fr/medias/8264supporting-quality-journalism-through-media-and-information-literacy.html

Debord, G. (1999). La sociedad del espectáculo. Pre-Textos.

Didi-Huberman, G. (2004). Imágenes pese a todo: Memoria visual del Holocausto. Paidós.

Didi-Huberman, Georges (2012). Arde la imagen. Serieve.

Didi-Huberman, G. (2013). Cuando las imágenes toman posición. Antonio Machado.

Domínguez-Rigo, Miguel (2020). La alfabetización visual como defensa ante las noticias falsas. $\begin{array}{lllll}\text { Revista de Estilos de } & \text { Aprendizaje, } & \text { 13(26), }\end{array}$ http://revistaestilosdeaprendizaje.com/article/view/2012/3209

Ferrés Prats, Joan (2020). Grandes carencias de la educación mediática. Temas de Comunicación, 41, 8-18. http://revistasenlinea.saber.ucab.edu.ve/temas/index.php/temas/article/download/4726/3940

Friedberg, A. (1993). Window Shopping. Cinema and the Postmodern. University of California Press.

Gallardo-Camacho, Jorge; Marta-Lazo, Carmen (2020). Editorial. La verificación de hechos (fact checking) y el pensamiento crítico para luchas contra las noticias falsas: alfabetización mediática como reto comunicativo y educativo. Revista de Estilos de Aprendizaje, (13(26), 4-6. http://revistaestilosdeaprendizaje.com/article/view/2594

Gómez Tarín, F. J. (2011). Elementos de narrativa audiovisual: expresión y narración. Shangrila.

González Requena, J. (1988). El discurso televisivo: espectáculo de la posmodernidad. Cátedra. 
González Requena, J. (2002). 11 de Septiembre: escenarios de la postmodernidad. Trama \& Fondo: Revista de Cultura, 12: 7-18. https://dialnet.unirioja.es/servlet/articulo?codigo=2248487

Greimas, A. J. (1990). Del Sentido II: Ensayos semióticos. Madrid: Gredos.

Han, Byung Chul (2018). Buen entretenimiento. Una deconstrucción de la historia occidental de la Pasión. Herder.

Hirsch, M. (2001). Surviving Images: Holocaust Photographs and the Work of Postmemory. The Yale Journal of Criticism, 14(1): 5-37. https://doi.org/10.1353/yale.2001.0008

Iturralde, V. (2021). De Narciso a Orfeo. Identidad narrativa y espectatorial en Twin Peaks: The Return de David Lynch. Signa, 30: 323-338. https://doi.org/10.5944/signa.vol30.2021.29313

Kahana, J. (2016). The Documentary Film Reader: History, Theory, Criticism. Oxford University Press.

Keller, F. B.; David Schoch, S. S. \& Jung Hwan, Y. (2020). Political Astroturfing on Twitter: How to Coordinate a Disinformation Campaign. Political Communication 37(2): 256-80. https://doi.org/10.1080/10584609.2019.1661888

Lanier, J. (2020). Diez razones para borrar tus redes sociales de inmediato. Debate.

Lanzmann, C. (2011). La liebre de la Patagonia. Seix Barral.

Levitsky, S. \& Ziblatt, D. (2018). Cómo mueren las democracias. Ariel.

López-Rico, C. M.; González-Esteban, J. L. \& Hernández-Martínez, A. (2020). Polarización y confianza en los medios españoles durante el Covid-19. Identificación de perfiles de audiencia. Revista Española de Comunicación en Salud, Suplemento 1: 77-89. https://doi.org/10.20318/recs.2020.5439

Lotero-Echeverri, G.; Romero-Rodríguez, L. M. \& Pérez Rodríguez, M. Amor (2018). Fact-checking vs. Fake News: Periodismo de confirmación como recurso de la competencia mediática contra la desinformación. $\quad$ Index.comunicación, $\quad 8(2), \quad$ 295-316. https://journals.sfu.ca/indexcomunicacion/index.php/indexcomunicacion/article/view/370

Lyon, D. (2000). Jesus in Disneyland: Religion in Postmodern Times. Polity Press.

Lyotard, J.-F. (1987). La condición posmoderna. Informe sobre el saber. Cátedra.

Martín-Núñez, M. \& Navarro Remesal, V. (2021). La complejidad ludonarrativa en el videojuego: un doble Boomerang. L'Atalante. Revista de Estudios Cinematográficos, 31: 7-31. http://revistaatalante.com/index.php?journal=atalante\&page=article\&op=view\&path $\% 5 \mathrm{~B} \% 5 \mathrm{D}=9$ 02\&path\%5B $\% 5 \mathrm{D}=632$

Marzal-Felici, J. \& Gómez Tarín, F. J. (eds.) (2007). Metodologías de análisis del film. Edipo. 
Marzal-Felici, J. \& Soler-Campillo, M. (2018). El espectáculo del exceso. Representaciones de la crisis financiera de 2008 en el cine mainstream norteamericano. Revista Latina de Comunicacion Social (73): 89-114. http://www.revistalatinacs.org/073paper/1247/06es.html

Marzal-Felici, J. (2007). Cómo se lee una fotografía. Interpretaciones de la mirada. Cátedra.

Marzal-Felici, J. (2021). Propuestas para el estudio de las imágenes en la era de la posverdad. Profesional de la información, v. 30, n. 2, e300201. https://doi.org/10.3145/epi.2021.mar.01

Mekas, J. (2013). Diario de Cine. El nacimiento del nuevo cine norteamericano. Mangos de hacha.

Mendik, X. \& Schneider, S. J. (2002). Underground U.S.A.: Filmaking Beyond the Hollywood Canon. Wallflower.

Mottola, S. (2020). Las fake news como fenómeno social. Análisis lingüístico y poder persuasivo de bulos en italiano y español. Discurso \& Sociedad 14(3): 683-706. http://www.dissoc.org/ediciones/v14n03/DS14\%283\%29Nardaccio.html

Mounk, Y. (2018). El pueblo contra la democracia: Por qué nuestra libertad está en peligro y cómo salvarla. Paidós.

Nieto Ferrando, J. \& Aranzubía Cob, A. (2020). Las revistas académicas de estudios fílmicos. Una cartografía. Secuencias 51: 11-38. https://doi.org/10.15366/secuencias2020.51.001

Nussbaum, M. C. (2019). La monarquía del miedo: Una mirada filosófica a la crisis política actual. Paidós.

Palao Errando, J. A. (2016). La reducción enunciativa: Podemos y la constricción de la voz de la multitud. Obets 11(1): 255-285. https://doi.org/10.14198/OBETS2016.11.1.10

Pedriza, S. B. (2017). El Slow Journalism en la era de la 'Infoxicación.' Doxa Comunicación: Revista Interdisciplinar de Estudios de Comunicación y Ciencias Sociales (25): 129-148. https://doi.org/10.31921/doxacom.n25a6

Pérez-Curiel, Concha; Velasco Molpeceres, Ana María (2020). Impacto del discurso político en la difusión de bulos sobre Covid-19. Influencia de la desinformación en públicos y medios. Revista Latina de Comunicación Social, 78, 67-97. https://www.doi.org/10.4185/RLCS-2020-1469

Pierri, F.; Piccardi, C. \& Ceri, S. (2020). A Multi-Layer Approach to Disinformation Detection in US and Italian News Spreading on Twitter. EPJ Data Science 9(1). https://doi.org/10.1140/epjds/s13688-020-00253-8

Quintana, Àngel (2003). Fábulas de lo visible: El cine como creador de realidades. El Acantilado.

Rancière, J. (2011). El destino de las imágenes. Politopías.

Rivette, J. (2010). De la abyección. Cahiers du Cinema. España 36: 58-59.

Rodríguez, R. (2018). Máscaras de la mentira: El nuevo desorden de la posverdad. Pre-textos. 
Rodríguez Serrano, A. (2017). Verdad, narrativa audiovisual y periodismo: Una aproximación crítica desde la filosofía. Estudios sobre el Mensaje Periodístico, 23(2): 955-968. https://doi.org/10.5209/ESMP.58026

Rodríguez Serrano, A.; Palao Errando, J. A. \& Marzal Felici, J. (2019). Los estudios fílmicos en el contexto de las ciencias sociales: un análisis de autores, objetos y metodologías en las revistas de impacto españolas (2012-2017). BID: Textos Universitarios de Biblioteconomía y Documentación, 43. https://dx.doi.org/10.1344/BiD2019.43.7

Romero-Rodríguez, L. M. \& Rodríguez-Hidalgo, C. (2019). Desinformación y posverdad en los medios digitales: del astroturfing al click-baiting. En: Romero-Rodríguez, L. M. \& Rivera Rogel, D. E., La comunicación en el escenario digital. Actualidad, retos y prospectivas. México: Pearson, 379-408.

Romero-Rodríguez, L. M.; Tejedor, Santiago \& Castillo-Abdul (2021). From the Immediacy of the Cybermedia to the Need for Slow Journalism: Experiences from Ibero-America. Journalism Practice. https://doi.org/10.1080/17512786.2020.1870530

Romero-Rodríguez, L. M.; Valle Razo, A. L.; Torres Toukoumidis, Á. (2018). Hacia una construcción conceptual de las fake news: epistemologías y tipologías de las nuevas formas de desinformación. En: M. J. Pérez Serrano, G. Alcolea-Díaz y A. I. Nogales-Bocio, Poder y medios en las sociedades del siglo XXI, Egregius Ediciones, 259-273.

Steyerl, H. (2014). Los condenados de la pantalla. Caja Negra Editora.

Todorov, T. (2012). Los enemigos íntimos de la democracia. Galaxia Gutenberg.

Ufarte-Ruiz, M.-J.; Peralta-García, L.; Murcia-Verdú, F.-J. (2018). Fact Checking: un nuevo desafío del periodismo. El profesional de la información, 27(4), 733-741. https://doi.org/10.3145/epi.2018.jul.02

Ufarte-Ruiz, M. J., Anzera, G. y Murcia-Verdú, F. J. (2020). Plataformas independientes de factchecking en España e Italia. Características, organización y método. Revista Mediterránea de Comunicación/Mediterranean Journal of Communication, 11(2), 23-39. https://www.doi.org/10.14198/MEDCOM2020.11.2.3

Vázquez-Herrero, J.; Vizoso, Á.; López-García, X. (2019). Innovación tecnológica y comunicativa para combatir la desinformación: 135 experiencias para un cambio de rumbo. El profesional de la información, 28(3), 1-12. https://doi.org/10.3145/epi.2019.may.01

Wajcman, G. (2001). El objeto del siglo. Amorrortu.

Wardle, Claire; Derakhshan, Hossein (2017). Information Disorder. Toward an inyerdisciplinary framework for research and policy making. Strasburgo: Council of Europe. https://rm.coe.int/information-disorder-toward-an-interdisciplinary-framework-for$\underline{\text { researc/168076277c }}$

Žižek, S. (2002). Bienvenidos al desierto de lo real. Akal. 
RLCS, Revista Latina de Comunicación Social, 79, 19-42

[Investigación] DOI: 10.4185/RLCS-2021-1506| ISSN 1138-5820| Año 2021

Zumalde, I. \& Zunzunegui, S. (2015). Con la verdad por delante. Apuntes sobre la verosimilitud de imagen.

Quintana, $14(14)$,

247-259.

https://revistas.usc.gal/index.php/quintana/article/view/1860.

Zunzunegui, S. (1995). Pensar La Imagen. Cátedra.

Zunzunegui, S. (2005). Las cosas de la vida: Lecciones de semiótica estructural. Biblioteca Nueva.

Zunzunegui, S. \& Zumalde, I. (2018). La era del saber fungible. En: Rodríguez Serrano, Aaron y Gil Soldevilla, Samuel, Investigar en la era neoliberal. Visiones críticas sobre la investigación en comunicación en España. Aldea Global, pp. 55-70.

Zunzunegui, Santos; Zumalde, Imanol (2019). Ver para creer: Avatares de la verdad cinematográfica. Cátedra.

\section{AUTORES:}

\section{Aaron Rodríguez Serrano}

Profesor Contratado Doctor de Comunicación Audiovisual y Publicidad en la Universitat Jaume I. Máster en Historia y Estética de la Cinematografía (Universidad de Valladolid) y Coordinador del Máster en Nuevas Tendencias y Procesos en Comunicación (UJI). Es Graduado en Filosofía (UNED) y egresado de los seminarios de Yad Vashem (Jerusalem). Ha publicado diferentes libros entre los que destacan Apocalipsis pop! El cine de las sociedades del malestar (Madrid: Notorious, 2012); Espejos en Auschwitz: Apuntes sobre cine y Holocausto (Ed. Shangrila, 2015); Melancolía (Valencia: Nau Llibres, 2016); Ghost in the Shell. Nostalgia de la encarnación (Santander: Shangrila, 2017); Nanni Moretti (Madrid: Cátedra, 2018); y Nunca le oímos llorar. Apunte sobre Joker (Todd Phillips, 2019) (Santander: Shangrila, 2020). Associate Professor of Audiovisual Communication and Advertising at the Universitat Jaume I. Master in History and Aesthetics of Cinematography (University of Valladolid) and Coordinator of the Master in New Trends and Processes in Communication (UJI). He is a graduate in Philosophy (UNED) and a graduate of the Yad Vashem seminars (Jerusalem). He has published several books including Apocalipsis pop! El cine de las sociedades del malestar (Madrid: Notorious, 2012); Espejos en Auschwitz: Apuntes sobre cine y Holocausto (Ed. Shangrila, 2015); Melancolía (Valencia: Nau Llibres, 2016); Ghost in the Shell. Nostalgia for Incarnation (Santander: Shangrila, 2017); Nanni Moretti (Madrid: Cátedra, 2018); and Nunca le oímos llorar. Apunte sobre Joker (Todd Phillips, 2019) (Santander: Shangrila, 2020).

serranoa@uji.es

Índice H: 8

Orcid ID: http://orcid.org/0000-0002-3858-1045

Google Scholar:

https://scholar.google.es/citations?hl=ca\&user=notIa2EAAAAJ\&view_op=list_works\&sortby=pubd $\underline{\text { ate }}$

Researchgate: https://www.researchgate.net/profile/Aaron-Rodriguez-Serrano

Academia.edu: https://uji.academia.edu/AarónRodr\%C3\%ADguezSerrano

\section{María Soler-Campillo}

Licenciada en Ciencias Económicas y Empresariales por la Universitat de València, Máster en Asesoría Fiscal por el Instituto de Estudios Superiores del CEU-San Pablo de Valencia, Doctora en Comunicación Empresarial e Institucional, es Profesora Contratada Doctora de Empresas de 
comunicación y Empresa audiovisual en la Universitat Jaume I. Ha participado, entre otros, en los libros colectivos (Re)viewing Creative, Critical and Commercial Practices in Contemporary Spanish Cinema (Chicago: Intelect, 2014); La crisis de lo real. Representaciones de la crisis financiera de 2008 en el audiovisual contemporáneo (Valencia: Tirant Lo Blanch, 2018); y es co-editora de Participación ciudadana y medios de comunicación públicos I. Conceptos y teorías (Valencia: Tirant Lo Blanch, 2021).

solerm@uji.es

Índice H: 8

Orcid ID: http://orcid.org/0000-0002-3237-8038

Google Scholar: https://scholar.google.es/citations?user=Yn8OyXcAAAAJ\&hl=es

\section{Javier Marzal-Felici}

Catedrático de Comunicación Audiovisual y Publicidad en la Universitat Jaume I de Castellón. Director del Departamento de Ciencias de la Comunicación, Coordinador del Programa de Doctorado en Ciencias de la Comunicación y del Grupo de Investigación «ITACA-UJI», cuyos intereses se centran en el estudio de la cultura visual, las relaciones entre tecnología y visualidad, la teoría de la imagen, la economía política de la comunicación y el análisis de textos audiovisuales. Entre sus últimos trabajos destacan la co-edición de la obra colectiva La crisis de lo real. Representaciones de la crisis financiera de 2008 en el audiovisual contemporáneo (Valencia: Tirant Lo Blanch, 2018); y Participación ciudadana y medios de comunicación públicos I. Conceptos y teorías (Valencia: Tirant Lo Blanch, 2021).

marzal@uji.es

Índice H: 15

Orcid ID: http://orcid.org/0000-0002-2462-1122

Google Scholar: $\underline{\text { https://scholar.google.es/citations?hl=es\&user=jAqLLqsAAAAJ }}$

ResearchGate: https://www.researchgate.net/profile/Javier-Marzal-Felici

Academia.edu: https://uji.academia.edu/JavierMarzalFelici 